\title{
The Impact of International and National Credit Rating Level on Capital Structure Optimization: Evidence from Indonesia Non-Financial Listed Firms
}

\author{
Christina*, Mandra Lazuardi Kitri \\ School of Business and Management, Institut Teknologi Bandung, Bandung City, 40132, Indonesia
}

Received July 12, 2021; Revised August 24, 2021; Accepted September 21, 2021

\section{Cite This Paper in the following Citation Styles}

(a): [1] Christina, Mandra Lazuardi Kitri , "The Impact of International and National Credit Rating Level on Capital Structure Optimization: Evidence from Indonesia Non-Financial Listed Firms," Universal Journal of Accounting and Finance, Vol. 9, No. 5, pp. 995 - 1008, 2021. DOI: 10.13189/ujaf.2021.090510.

(b): Christina, Mandra Lazuardi Kitri (2021). The Impact of International and National Credit Rating Level on Capital Structure Optimization: Evidence from Indonesia Non-Financial Listed Firms. Universal Journal of Accounting and Finance, 9(5), 995 - 1008. DOI: 10.13189/ujaf.2021.090510.

Copyright $\bigcirc 2021$ by authors, all rights reserved. Authors agree that this article remains permanently open access under the terms of the Creative Commons Attribution License 4.0 International License

\begin{abstract}
Credit rating is a measure of a firm's creditworthiness in financial markets. The cost and benefit given from credit rating is supposed to affect the capital structure decision in the following year. This research examines the effect of each rating level on the capital structure level and examines how credit ratings are substantial for the firms to reach the optimal capital structure. It will also compare the impact of credit ratings from different agencies. Quarterly data of 110 firms that fulfil the requirements are gathered from 2010 until 2021. Panel data analysis using the fixed effects method shows a nonlinear U-shape between Standard \& Poor's and Fitch's credit rating on capital structure level and on the distance to optimal capital structure level. Low and high rated firms tend to have higher debt levels in the following year and have a larger distance to the optimal capital structure level. Meanwhile, mid rated firms have lower debt levels and smaller distances. However, the result is opposite using Moody's rating and insignificant using PEFINDO's rating. This research suggests that credit rating is important to the capital structure decisions and other Indonesia firms could acquire credit rating especially from international rating agency.
\end{abstract}

Keywords Credit Rating, Capital Structure, Optimal Capital Structure

\section{Introduction}

As of today, there are still an ongoing debate in academic literature about which and how determinants influence the capital structure decision. Before credit rating-capital structure theory from Kisgen[1] is introduced, credit rating has been neglected from the capital structure determinants. Whereas, credit rating is an objective assessment to measure the creditworthiness or firm's ability to fulfil the financial obligations in a timely manner. A certain credit rating affects the image of the firm. Low credit rating shows a bad image since it represents high credit risk or low ability of the firm to fulfil its financial obligations within the due dates. Thus, they usually provide high interest or coupons to get funding through bonds. Therefore, the credit rating level of a firm implies different costs and benefits and is supposed to affect the capital structure of a firm in the next period. Supported by other studies, credit rating is one of the most important variables in making the capital structure decisions [2], [3].

Reviewing the previous research presents contradictory results and gaps. First, there are none of the previous researches that examine the credit rating on the distance of actual and optimal capital structure. Therefore, this research not only saw the impact of credit rating level on capital structure level, but also examine whether the capital structure decision made following the credit rating 
level is endeavoured to maintain or lessen the distance between actual and optimal capital structure.

Second, there is only a little research that examines the effect of credit rating from different rating agencies. In Indonesia, firms could have credit ratings from different rating agencies. Firms may have national credit rating PEFINDO, and/or international rating such as Standard \& Poor's, Moody's, and Fitch. Knowing how each top 3 international rating agency and national agency impacts the capital structure decision of firms will give more broad results about the credit rating significance. Therefore, this research will determine how each rating agency gives impact in the Indonesia firm's capital structure decision.

Third, even if the research about credit rating significance on capital structure is growing, there are still several studies in different countries that exclude the credit rating as one of the capital structure determinants. Therefore, this research would like to enrich the international debate by examining the Indonesia context. This research would like to validate and evaluate the effect of both national and international credit rating on the capital structure decision of Indonesia non-financial listed firms. The firms taken as the sample should be listed in IDX and classified in non-financial firms since financial firms have different credit ratings. Moreover, the firms have to be rated by one national rating agency or minimum one international rating agency. Eventually, 110 firm's quarterly data are gathered from 2010 until the first quarter of 2021 since prior to the year of 2010, there is much data that is unavailable.

\section{Literature Review}

This section explains the details about the theoretical foundation that was used in this research.

\subsection{Capital Structure}

Capital Structure refers to the combination of long-term debt and equity used by a firm, to finance their operation process and assets (Figure 1). Although using debt is cheaper than equity, if the firm relies too much on debt, it will increase the risk of default in repayment. As well as using equity in order to reduce debt risks, relying too high on equity resulting in shares dilution or decreasing present shareholder's value in the firm. Therefore, capital structure decisions should be properly managed to the optimal level. With optimal capital structure, firms could minimize the cost of capital and increase the firm's value. Modigliani and Miller[4] presented one of the first theories that debt has no advantages for firms and thus a firm's value should be independent from its capital structure. However, the realization of the tax advantages of debt financing led Modigliani and Miller[5] to conclude that capital structure is relevant to the total value of the firm, since the value of levered firms get higher than unlevered firms with the same risk, due to tax deductibility on interest.

Afterwards, two theories namely the trade-off theory and pecking order theory become the most common theories to explain how firms determine their capital structure and financing choices. In the trade-off theory, the capital structure decisions depend on the optimal level of capital structure which happens when there are balances between the benefits from tax advantages of debt financing and the cost from financial distress [6], [7]. In pecking order theory, firms finance their activities with retained earnings when feasible. The order of financial sources used was internal funds from profits, short-term securities, debt, preferred stock, and common stock [7].

As of today, there are still on-going debates in academic literature about which and how determinants influence the capital structure decision. Tangibility, liquidity, profitability, firm size, and business growth are commonly used to determine the capital structure factors. Previous studies presented contradictory results. Some results support the trade-off theory but others support the pecking order theory. The five capital structure determinants that are mentioned will be the control variables in this research and the detail could be seen in the later sections.

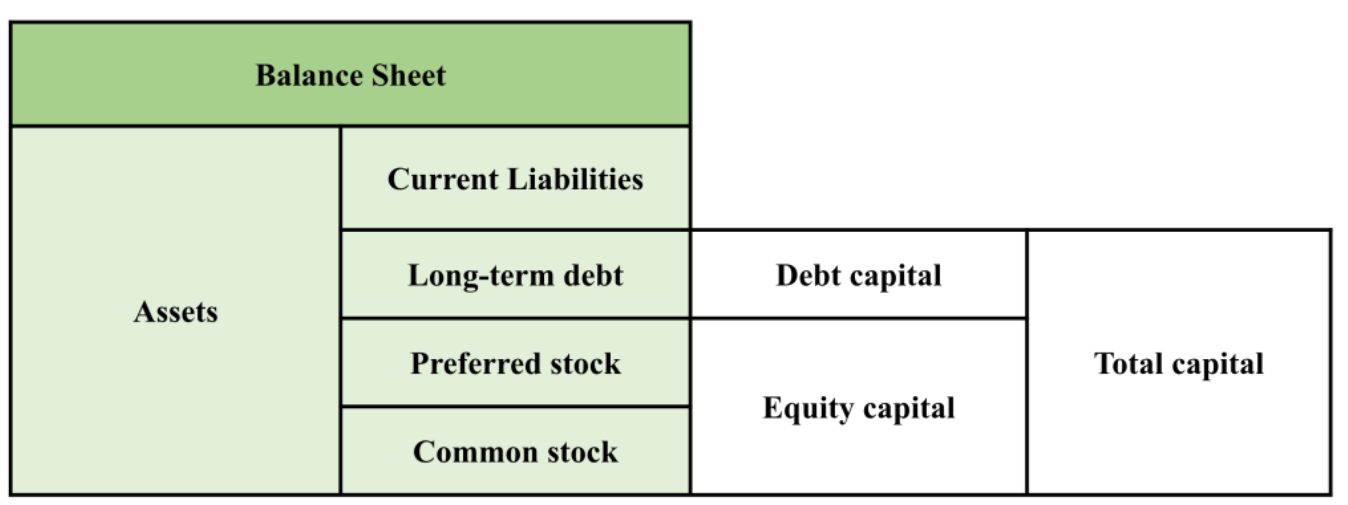

Figure 1. Capital Structure Composition 


\subsection{Credit Rating}

Credit rating is an objective assessment to measure the creditworthiness or firm's ability to fulfil the financial obligations in a timely manner. The function of credit rating at the firm level is to reflect the possibility of firms to pay their debt back without issues or being default. Generally, there are two big categories in credit rating which are investment grade and speculative grade. Following the Standard \& Poor's credit rating, investment grade consists of rates from AAA, AA, A and BBB. It can be said that this category has a high credit rating and has lower risk of default. The other category is speculative grade that consists of $\mathrm{BB}, \mathrm{B}, \mathrm{CCC}, \mathrm{CC}, \mathrm{C}$ and $\mathrm{D}$. This category has low credit rating and higher risk of default and is commonly referred to as junk bonds.

High credit rating reflects that firms are able to pay their debt corresponding with the loan agreement and thus resulting lower risk. Whereas, low credit rating reflects higher risk since firms are having trouble to fulfill the financial obligations. Last, default credit rating means that the firms are already stated unable to pay the principal debt and/or the interest. With lower rating and higher risk, firms normally increase their interest offer to the bondholders to get funding. Therefore, credit rating is assumed to affect the cost of debt and thus affects the firm's value as well.

\subsection{Credit Rating Significance on Capital Structure}

Credit ratings are a material consideration in manager's capital structure decisions due to the costs (benefits) associated with different rating levels [1]. Both upgrades and downgrades of credit rating affect significantly capital structure decisions of the American listed firms of the following year [8]. Downgraded firms to speculative grade reduce their debt issuance in the following year to reach the investment grade again. However, if the firms already reach the investment grade, they will increase their debt issuance without fear of being downgraded again. In contrast, Latin America, Germany, and Indonesia listed firms are not taking into account the credit rating changes to their capital structure decisions [9], [10], [11].

Meanwhile, with a different approach by using credit rating ordinal level instead of credit rating changes, there is a nonlinear inverted U-shape relationship between credit rating level and capital structure decisions of Asian and Pakistani listed firms [12], [13]. Mid-rated firms have a high level of debt while high and low-rated firms have a low level of debt. The different results of several empirical studies lead the researcher to assess the credit rating significance on capital structure decisions of Indonesia non-financial listed firms.

\section{Materials and Methodology}

This section discusses the details of procedures to answer the research objectives and draw conclusions.

\subsection{Hypothesis Development}

Departing from the previous research, it can be concluded that credit rating has a contradictory relationship on capital structure. Moreover, there are still gaps that has not been examined. Thus, this research will examine the impact of credit rating level on capital structure level and on the distance between actual and optimal capital structure. The credit rating will be differentiate using international credit rating agencies (Standard \& Poor, Moody's, Fitch) and national credit rating agency (PEFINDO). Besides, this research also includes control variables to separate their impact to the dependent variable. The model and hypothesis developed are shown in the Figure 2.

The hypotheses developed are departing from the previous researches which stated that credit rating has a significance effect in capital structure decision. First, this research developed hypotheses of the relationship between credit rating on the capital structure level in the following year. The hypotheses will be differentiated by different rating agencies following the Sajjad and Zakaria[12] recommendation. Thus, the hypotheses proposed as follows:

$\mathrm{H} 1=$ Standard \& Poor's credit rating has a significant effect on the firm's capital structure level in the following year

$\mathrm{H} 2$ = Moody's credit rating has a significant effect on the firm's capital structure level in the following year

H3 = Fitch's credit rating has a significant effect on the firm's capital structure level in the following year

H4 = PEFINDO's credit rating has a significant effect on the firm's capital structure level in the following year.

Hereafter, this research developed hypotheses to assess the extent effect of credit rating which is the effect on the distance to optimal capital structure. The hypotheses are in line with previous research that found that credit rating has an impact on closing the gap between actual and optimal capital structure [10], [14]. Similar to the first section hypotheses, the hypotheses will be differentiated by different agencies. The hypotheses proposed as follows:

H5 = Standard \& Poor's credit rating has a significant effect on a firm's distance to the optimal capital structure level in the following year

H6 = Moody's credit rating has a significant effect on a firm's distance to the optimal capital structure level in the following year

H7 = Fitch's credit rating has a significant effect on a firm's distance to the optimal capital structure level in the following year

H8 = PEFINDO's credit rating has a significant effect on a firm's distance to the optimal capital structure level in the following year. 


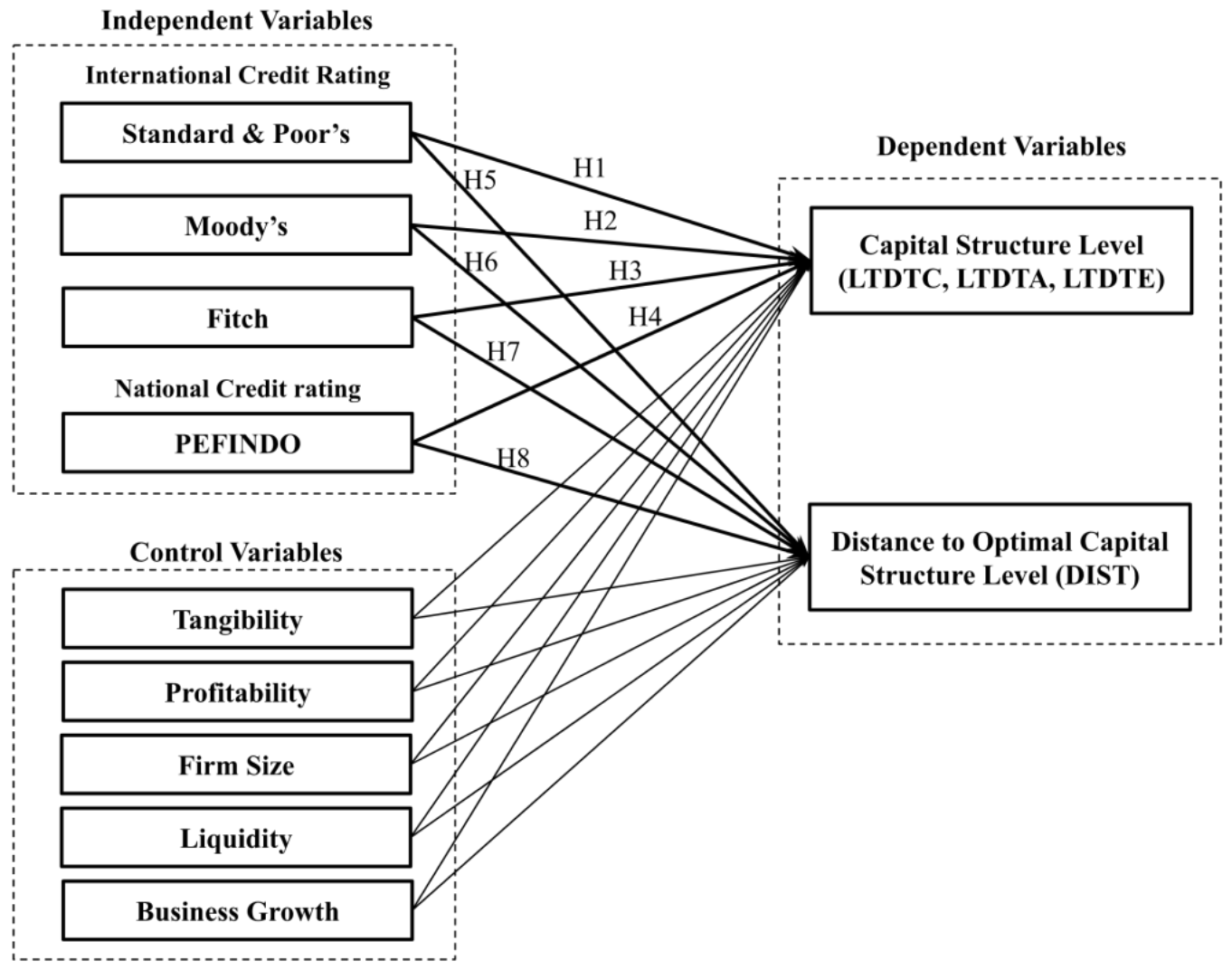

Figure 2. Hypotheses Development Model

\subsection{Operation Variables}

To test the relationship between credit rating and capital structure and to the distance to optimal capital structure level, the following dependent, independent, and control variables are used. The capital structure is measured using three proxies to increase the robustness, namely long-term debt to total capital ratio (LTDTC), long-term debt to total asset ratio (LTDTC), long-term debt to total equity ratio (LTDTC). The second dependent variable (DIST) is measured by the absolute distance between each capital structure proxy previously mentioned and the industry median leverage ratio (IMLR) of the previous period as the optimal level of capital structure. IMLR is used with assumptions that every sector has an optimal leverage ratio which becomes the target of firms that are in the industry.

The independent variables used are credit rating from difference rating agencies. This research uses Standard \& Poor's (CR1), Moody's (CR2), and Fitch (C3) rating as the international rating and PEFINDO's (CR4) rating as the national credit rating. The coding method is employed to transform the ordinal value of credit rating into numerical value, as shown in Table 1.

The international credit rating is standardized together and this research excluded the AAA rating code since it is not found at all in the data set. Moreover, the coding scheme is differentiated between international and national credit rating due to the big gap of rating code.

Table 1. Credit Rating and Assigned Numerical Coding

\begin{tabular}{|c|c|c|c|c|c|}
\hline \multicolumn{4}{|c|}{ International Credit Rating } & \multicolumn{2}{|c|}{ National Credit Rating } \\
\hline $\begin{array}{c}\text { Individual } \\
\text { Rating } \\
\text { Code } \\
\end{array}$ & $\begin{array}{c}\text { Standard } \\
\& \\
\text { Poor's }\end{array}$ & Moody's & Fitch & PEFINDO & $\begin{array}{c}\text { Individual } \\
\text { Rating } \\
\text { Code } \\
\end{array}$ \\
\hline 1 & $\mathrm{BBB}+$ & Baa1 & $\mathrm{BBB}+$ & idAAA & 1 \\
\hline 2 & BBB & Baa2 & BBB & idAA+ & 2 \\
\hline 3 & BBB- & Baa3 & BBB- & idAA & 3 \\
\hline 4 & $\mathrm{BB}+$ & $\mathrm{Ba} 1$ & $\mathrm{BB}+$ & idAA- & 4 \\
\hline 5 & BB & $\mathrm{Ba} 2$ & BB & $\mathrm{idA}+$ & 5 \\
\hline 6 & BB- & $\mathrm{Ba} 3$ & BB- & idA & 6 \\
\hline 7 & $\mathrm{~B}+$ & B1 & $\mathrm{B}+$ & idA- & 7 \\
\hline 8 & B & B2 & $\mathrm{B}$ & idBBB + & 8 \\
\hline 9 & B- & B3 & B- & idBBB & 9 \\
\hline 10 & $\mathrm{CCC}+$ & Caa1 & $\mathrm{CCC}+$ & idBBB- & 10 \\
\hline 11 & $\mathrm{CCC}$ & Caa2 & $\mathrm{CCC}$ & $\mathrm{idBB}+$ & 11 \\
\hline 12 & CCC- & $\mathrm{Caa} 3$ & $\mathrm{CCC}-$ & $\mathrm{idBB}$ & 12 \\
\hline 13 & $\mathrm{CC}$ & $\mathrm{Ca}$ & $\mathrm{CC}$ & idBB- & 13 \\
\hline 14 & $\mathrm{C}$ & $\mathrm{C}$ & $\mathrm{C}$ & $\mathrm{idB}+$ & 14 \\
\hline \multirow[t]{3}{*}{15} & SD & & $\mathrm{RD}$ & $\mathrm{idB}$ & 15 \\
\hline & & & & idB- & 16 \\
\hline & & & & idCCC & 17 \\
\hline
\end{tabular}

The international credit rating is standardized together and this research excluded the AAA rating code since it is 
not found at all in the data set. Moreover, the coding scheme is differentiated between international and national credit rating due to the big gap of rating code.

Moreover, there are 5 control variables used in this research, which are tangibility ratio, profitability ratio, firm's size, liquidity ratio, and business growth. This research combines the control variables that are most commonly used in the previous researches [12], [14], [15],
[16]. The use of control variables is to separate the impact of other factors than the interested variables to the dependent variable. By separating the impact of control variables to the dependent variable, the result obtained of the relationship between interested variables will have more reliable results.

The summary of variables used in this research are shown from Table 2 .

Table 2. Variables Definitions

\begin{tabular}{|c|c|c|c|}
\hline Variables & Code & Measurement & Explanation \\
\hline \multicolumn{4}{|c|}{ Dependent Variables } \\
\hline \multirow{3}{*}{$\begin{array}{l}\text { Capital Structure } \\
\quad \text { Level }\end{array}$} & LTDTC & $\begin{array}{l}\text { Long-term debt / } \\
\text { Total capital }\end{array}$ & $\begin{array}{l}\text { LTDTC is one of the common measurement leverage ratios of capital } \\
\text { structure. This proxy is used by Khaw[17], Chakrabarti \& } \\
\text { Chakrabarti[18], Workman \& Rosenberg[19], and Shah et al.[20] to } \\
\text { define capital structure. }\end{array}$ \\
\hline & LTDTA & $\begin{array}{l}\text { Long-term debt / } \\
\text { Total asset }\end{array}$ & $\begin{array}{l}\text { LTDTC is one of the common measurement leverage ratios of capital } \\
\text { structure. This proxy is used by Mirza et al.[16], Wojewodzki et } \\
\text { al.[14], Titman \& Wessels[21], and Nguyen et al.[22] to define capital } \\
\text { structure. }\end{array}$ \\
\hline & LTDTE & $\begin{array}{l}\text { Long-term debt / } \\
\text { Total equity }\end{array}$ & $\begin{array}{l}\text { LTDTC is one of the common measurement leverage ratios of capital } \\
\text { structure. This proxy is used by Myers[23], Mouton \& Smith[24], and } \\
\text { Nadeem et al.[25] to define capital structure. }\end{array}$ \\
\hline $\begin{array}{l}\text { Distance to Optimal } \\
\text { Capital Structure }\end{array}$ & DIST & $\begin{array}{l}\text { |LTDTC - Industry } \\
\text { median LTDTC|, } \\
\text { |LTDTA - Industry } \\
\text { median LTDTA|, } \\
\text { |LTDTE - Industry } \\
\text { median LTDTE| }\end{array}$ & $\begin{array}{l}\text { DIST measures the absolute distance between each capital structure } \\
\text { proxy and the industry median leverage ratio of the previous period as } \\
\text { the optimal level of capital structure. Industry median leverage ratio is } \\
\text { used with assumptions that every industry has an optimal leverage ratio } \\
\text { which becomes the target of firms that are in the industry. This proxy is } \\
\text { used by Hull[26], Graham \& Harvey[3], and Naomi et al.[27]. }\end{array}$ \\
\hline \multicolumn{4}{|c|}{ Independent Variables } \\
\hline \multirow{3}{*}{$\begin{array}{l}\text { International Credit } \\
\text { Rating }\end{array}$} & CR1 & $\begin{array}{l}\text { Please refer to Table } \\
1 \text { to check the } \\
\text { numerical coding. }\end{array}$ & $\begin{array}{l}\text { CR1 stands for Standard \& Poor's credit rating. The type of rating that } \\
\text { is used in this research is long-term issuer rating that is the most } \\
\text { commonly used in research. }\end{array}$ \\
\hline & CR2 & $\begin{array}{l}\text { Please refer to Table } \\
1 \text { to check the } \\
\text { numerical coding. }\end{array}$ & $\begin{array}{l}\text { CR2 stands for Moody's credit rating. The type of rating that is used in } \\
\text { this research is long-term issuer rating that is the most commonly used } \\
\text { in research. }\end{array}$ \\
\hline & CR3 & $\begin{array}{l}\text { Please refer to Table } \\
1 \text { to check the } \\
\text { numerical coding. }\end{array}$ & $\begin{array}{l}\text { CR3 stands for Fitch's credit rating. The type of rating that is used in } \\
\text { this research is long-term issuer rating that is the most commonly used } \\
\text { in research. }\end{array}$ \\
\hline $\begin{array}{l}\text { National Credit } \\
\text { Rating }\end{array}$ & CR4 & $\begin{array}{l}\text { Please refer to Table } \\
1 \text { to check the } \\
\text { numerical coding. }\end{array}$ & $\begin{array}{l}\text { CR4 stands for PEFINDO credit rating. The type of rating that is used } \\
\text { in this research is long-term issuer rating that is the most commonly } \\
\text { used in research. }\end{array}$ \\
\hline \multicolumn{4}{|c|}{ Control Variables } \\
\hline Tangibility & TANG & $\begin{array}{l}\text { Fixed Asset / Total } \\
\text { Asset }\end{array}$ & $\begin{array}{l}\text { High tangibility ratio linked to high debt levels according to Hovakimian } \\
\text { et al.[28] and Frank \& Goyal[29]. The results support the trade-off } \\
\text { theory. However, tangibility is also found to have a negative relationship } \\
\text { with capital structure according to Titman \& Wessels[21] and Booth et } \\
\text { al.[30]. The results support the pecking order theory. }\end{array}$ \\
\hline Profitability & PROF & $\begin{array}{l}\text { Earnings after tax / } \\
\text { total assets (ROA) }\end{array}$ & $\begin{array}{l}\text { High profitability ratio is linked to low debt levels [4]. The results } \\
\text { support the pecking order theory. However, profitability also found to } \\
\text { have a positive relationship with capital structure [31]. Thus, supporting } \\
\text { the trade-off theory. }\end{array}$ \\
\hline Firm Size & SIZE & Ln (total assets) & $\begin{array}{l}\text { Bigger firm size linked to high debt levels [21], [32], [33]. The results } \\
\text { support the trade-off theory. However, firm size may also have a } \\
\text { negative relationship with capital structure [34]. The result supports the } \\
\text { pecking order theory. }\end{array}$ \\
\hline Liquidity & LIQU & $\begin{array}{l}\text { Current assets / } \\
\text { current liabilities }\end{array}$ & $\begin{array}{l}\text { High liquidity ratio linked to low debt levels [35]. Thus, supporting the } \\
\text { pecking order theory. However, liquidity may also have a positive } \\
\text { relationship with capital [36]. The results support the trade-off theory. }\end{array}$ \\
\hline Business Growth & GROWTH & $\begin{array}{c}\% \text { Changes in total } \\
\text { assets }\end{array}$ & $\begin{array}{l}\text { High business linked to low debt levels according to Myers[37] and } \\
\text { Bevan \& Danbolt[38]. The results support the pecking order theory. } \\
\text { However, business growth may also have a positive relationship with } \\
\text { capital structure [38]. The result supports the trade-off theory. }\end{array}$ \\
\hline
\end{tabular}




\subsection{Population Sample and Data Source}

This research is focusing on non-financial firms listed on the Indonesia Stock Exchange since financial firms have different financial structures, special regulations, and different credit ratings from non-financial firms. Eventually, the main object of this research is 110 non-financial listed firms that have a national credit rating or minimum one international credit rating. Initially, this research used 45-quarterly time-series analysis from the first quarter of 2010 until the first quarter of 2021 since prior 2010, there are only few firms that have credit rating and there are several financial reports that are unavailable. However, this research uses the lag of one year relationship between the credit rating and capital structure which means that the dependent variable needs the credit rating data from the previous 4 quarters. Thus, the data used for dependent variables are only from the first quarter of 2011, indicating that the first quarter of 2010 until the fourth quarter of 2010 are unobservable and leaving the time-series to be only 41 quarters. All secondary data for dependent, independent, and control variables was gathered from the historical quarterly data of the financial report of each firm, using Thomson Reuters EIKON database.

\subsection{Statistical Model}

The statistical models divided into two dependent variables and stated as follow:

$$
\begin{aligned}
\operatorname{Capstru}_{\mathrm{it}}=\alpha_{0}+\alpha_{1} \mathrm{CR}_{\mathrm{it}-4} & +\alpha_{2} \mathrm{CR}_{\mathrm{it}-4}^{2}+\sum_{\mathrm{k}=1}^{5} \beta_{\mathrm{k}} \text { Control }_{\mathrm{k}, \mathrm{it}} \\
& +\varepsilon_{\mathrm{it}}(1) \\
\mathrm{DIST}_{\mathrm{it}}=\alpha_{0}+\alpha_{1} \mathrm{CR}_{\mathrm{it}-4} & +\alpha_{2} \mathrm{CR}_{\mathrm{it}-4}^{2}+\sum_{\mathrm{k}=1}^{5} \beta_{\mathrm{k}} \text { Control }_{\mathrm{k}, \mathrm{it}} \\
& +\varepsilon_{\mathrm{it}}(2)
\end{aligned}
$$

Equation (1) is the statistical model to assess the effect of credit rating level to the capital structure level of firm i at time t. Equation (2) is the statistical model to assess the effect of credit rating level to the distance to optimal capital structure level of firm $i$ at time $t$.

$\mathrm{Capstru}_{\mathrm{it}}$ is the capital structure level for firm i at time $\mathrm{t}$ and represented by long-term to total capital ratio (LTDTC), long-term to total asset ratio (LTDTA), or long-term to total equity ratio (LTDTE). The different proxies will be tested separately in different models. DIST $_{\text {it }}$ is the distance to optimal capital structure that is measured by the absolute subtraction of actual capital structure level for firm $i$ at time $t$ with the Industry Median Leverage Ratio (IMLR) from the previous year. The actual and optimal capital structure level will also be represented by three different proxies and tested separately in different models. $\mathrm{CR}_{\mathrm{it}-4}$ is the credit rating lagged one year or 4 quarters, while the $\mathrm{CR}^{2}{ }_{\mathrm{it}-4}$ is the square term of the credit rating to capture the non-linear relationship. The $\mathrm{CR}$ code could be $\mathrm{CR} 1, \mathrm{CR} 2, \mathrm{CR} 3$ or CR4 that represent credit ratings from different agencies. Besides, $\alpha_{0}$ is the intercept, $\alpha_{1}, \alpha_{2}$, and $\beta_{\mathrm{k}}$ are the slope parameters, Control $\mathrm{k}_{\mathrm{k}, \mathrm{t}}$ is the control variables, and $\varepsilon_{\mathrm{it}}$ is the error terms.

\subsection{Data Analysis Method}

There are three main ways to run a panel data, which are pooled OLS model, fixed effect model, and random effect model [39]. Pooled OLS is the simplest model which pools all of the observations, meaning that it disregards the space and time dimension. Thus, Pooled OLS assumed to be inefficient when dealing with panel data. This research preferred the fixed effect model over pooled OLS since it is perceived to have individual specific effects. Another alternative is the random effect which assumes that the variables are a random sampling and the model is efficient when the individual-specific has no correlation with the regressors. Fixed effect is preferable than random effect since the sample taken is not a random sampling and the individual-specific effects are perceived to be correlated with the independent variables. The Hausman test also applied to make sure that the fixed effect choice is better than random effect. This research runs all models but is not completely presented in this paper. Moreover, this research may not have utilized a generalized moment of method (GMM) that could have addressed the endogeneity problem due to preventing inefficiency in small samples that this research has using Moody's rating. This also becomes the limitations of this research and thus it's included as a recommendation for future research to validate the results. However, according to Sajjad and Zakaria[12] that also examine credit rating and capital structure, it is found that both fixed effect and GMM gave consistent results. Thus, utilizing fixed effects as the common method in panel data regression is presumed to be sufficient in this situation. Furthermore, the classical assumption test that consists of multicollinearity, heteroscedasticity, and autocorrelation is also being tested to make sure that the model is optimal and not biased. Meanwhile, the normality test is neglected since the number of observations is above 100. All panel regression was conducted using the RStudio program.

\section{Results and Discussion}

This section exhibits the result of the research, whether the hypotheses are accepted or rejected.

\subsection{Descriptive Statistics}

Due to space limitation, the statistical results presented are only with the LTDTC as the proxy of capital structure. 
Table 3. Descriptive Statistics

\begin{tabular}{|c|c|c|c|c|c|}
\hline Variable & Obs. & Mean & STD & Min & Max \\
\hline \multicolumn{6}{|c|}{ Model 1.1} \\
\hline DIST & 707 & 0.2732 & 0.2298 & 0.00038 & 2.317 \\
\hline LTDTC & 707 & 0.3886 & 0.2758 & 0 & 2.5217 \\
\hline CR1 & 707 & 7.0707 & 2.2343 & 3 & 15 \\
\hline TANG & 707 & 0.6121 & 0.1944 & 0.1575 & 0.98808 \\
\hline PROF & 707 & -00172 & 0.0622 & -1.2173 & 0.152 \\
\hline LIQU & 707 & 2.195 & 1.8876 & 0.00837 & 11.134 \\
\hline GROWTH & 707 & 0.0654 & 0.1690 & -0.6822 & 1.0008 \\
\hline SIZE & 707 & 30.778 & 0.7308 & 28.4244 & 32.494 \\
\hline \multicolumn{6}{|c|}{ Model 2.1} \\
\hline DIST & 155 & 0.1662 & 0.109 & 0.00335 & 0.4311 \\
\hline LTDTC & 155 & 0.3248 & 0.1598 & 0.0488 & 0.6392 \\
\hline CR2 & 155 & 2.5484 & 1.0457 & 1 & 4 \\
\hline TANG & 155 & 0.7227 & 0.1232 & 0.3462 & 0.8959 \\
\hline PROF & 155 & 0.0156 & 0.0187 & -0.0399 & 0.05101 \\
\hline LIQU & 155 & 1.2099 & 0.8129 & 0.2796 & 4.2848 \\
\hline GROWTH & 155 & 0.0835 & 0.1083 & -0.155 & 0.4135 \\
\hline SIZE & 155 & 32.082 & 0.4872 & 31.177 & 33.1402 \\
\hline \multicolumn{6}{|c|}{ Model 3.1} \\
\hline DIST & 615 & 0.2650 & 0.1878 & 0.0015 & 1.8592 \\
\hline LTDTC & 615 & 0.4057 & 0.2091 & 0 & 2.2681 \\
\hline CR3 & 615 & 6.099 & 2.5212 & 1 & 15 \\
\hline TANG & 615 & 0.6099 & 0.2051 & 0 & 0.9881 \\
\hline PROF & 615 & 0.0047 & 0.0392 & -0.4917 & 0.152 \\
\hline LIQU & 615 & 2.1227 & 1.7954 & 0.0091 & 11.0991 \\
\hline GROWTH & 615 & 0.0888 & 0.1780 & -0.4447 & 1.10694 \\
\hline SIZE & 615 & 30.906 & 0.9187 & 28.9921 & 33.1402 \\
\hline
\end{tabular}

Table 3. Descriptive Statistics (Cont.)

\begin{tabular}{cccccc}
\hline & \multicolumn{5}{c}{ Model 4.1 } \\
\hline DIST & 1212 & 0.1786 & 0.2297 & 0.00002 & 4.2218 \\
LTDTC & 1212 & 0.2777 & 0.2453 & 0 & 4.3071 \\
CR4 & 1212 & 5.773 & 2.5873 & 1 & 18 \\
TANG & 1212 & 0.5438 & 0.1994 & 0.018 & 0.9881 \\
PROF & 1212 & 0.0055 & 0.0538 & -0.978 & 0.7061 \\
LIQU & 1212 & 1.5829 & 1.1104 & 0.0091 & 13.0742 \\
GROWTH & 1212 & 0.1165 & 0.2152 & -0.7858 & 1.6088 \\
SIZE & 1212 & 30.091 & 1.3376 & 26.167 & 33.140 \\
\hline
\end{tabular}

Based on the Table 3 above, the mean of each capital structure level across the credit rating type was not very different from each other. However, the number of observations is different due to the different firms included in each credit rating model, which then probably show different characteristics. In total, there are 36 firms rated by Standard \& Poor's with 707 total observations, 7 firms rated by Moody's with 155 total observations, 36 firms rated by Fitch with 615 total observations, and 69 firms rated by PEFINDO with 1212 total observations. Results using other proxies which are LTDTA and LTDTE are available upon request. As additional information, although firms that are rated by Moody's are only 7 , the total observations are still above 100 , which then still allows panel data to get conclusions. 


\subsection{Regression Results}

The table exhibits the panel data regression result of 4 models with LTDTC as the capital structure proxy but different credit rating agencies. Model 1.1 uses Standard $\&$ Poor's, model 2.1 uses Moody's, model 3.1 uses Fitch, and model 4.1 uses PEFINDO's rating. The model applied a cross-sectional fixed effect technique. Time series is 41 quarters between 2011-2021. TANG is tangibility ratio;
PROF is profitability ratio; LIQU is liquidity ratio; GROWTH is business growth; SIZE is firm size. The Hausman Test is to validate that the fixed effect model is more preferable than random effect; VIF score is to check multicollinearity; White test is to check heteroscedasticity; Wooldridge test is to check autocorrelation. Models with heteroscedasticity and/or autocorrelation problems use robust standard error estimation. *,**,*** indicates significance level at $10 \%, 5 \%$ and $1 \%$, respectively.

Table 4. Regression Results of Credit Rating on Capital Structure Level

\begin{tabular}{|c|c|c|c|c|c|c|c|c|}
\hline \multicolumn{9}{|c|}{ Dependent Variable: Capital Structure Level } \\
\hline Coefficient & (1.1) & VIF score & $(2.1)$ & VIF score & (3.1) & VIF score & (4.1) & VIF score \\
\hline Hausman & 0.00019 & & 0.00000 & & 0.00000 & & 0.00030 & \\
\hline White Test & 0.00000 & & 0.06032 & & 0.00000 & & 0.00000 & \\
\hline Wooldridge & 0.00000 & & 0.00000 & & 0.00000 & & 0.00000 & \\
\hline Constant & 1.35364 & & $-3.12253^{* * *}$ & & 0.67300 & & 1.76302 & \\
\hline $\mathrm{CR}$ & $-0.12671^{* * *}$ & 8.521276 & $0.11671^{* * *}$ & 12.207166 & $-0.11677^{* * *}$ & 8.799035 & -0.09097 & 10.718867 \\
\hline $\mathrm{I}\left(\mathrm{CR}^{2}\right)$ & $0.00762^{* * *}$ & 7.369871 & $-0.02630^{* * *}$ & 10.355810 & $0.00956^{* * *}$ & 6.363236 & 0.00728 & 7.472138 \\
\hline TANG & 0.09093 & 3.709577 & $0.07141^{* *}$ & 3.753164 & -0.23806 & 4.544570 & $0.73646^{*}$ & 4.133698 \\
\hline PROF & $0.59629^{* * *}$ & 1.201957 & $-0.81605^{* *}$ & 2.035349 & -0.20536 & 1.336819 & -0.52997 & 1.167972 \\
\hline LIQU & 0.01587 & 2.455895 & $0.02236^{* *}$ & 3.022430 & $0.02044^{* * *}$ & 2.400219 & $0.06385^{* * *}$ & 2.401743 \\
\hline GROWTH & 0.02897 & 1.275291 & -0.01056 & 1.228520 & -0.06861 & 1.245745 & 0.02289 & 1.252379 \\
\hline SIZE & -0.00292 & 3.037397 & $0.10387^{* * *}$ & 3.309809 & 0.00908 & 4.185630 & -0.05731 & 5.878825 \\
\hline Observations & 707 & & 155 & & 615 & & 1,212 & \\
\hline $\mathrm{R}^{2}$ & 0.59023 & & 0.96117 & & 0.76813 & & 0.60157 & \\
\hline Adjusted $\mathrm{R}^{2}$ & 0.56431 & & 0.95759 & & 0.75110 & & 0.57564 & \\
\hline F Statistic & $22.77217^{* * *}$ & & $268.45140^{* * *}$ & & $45.11659^{* * *}$ & & $23.19878^{* * *}$ & \\
\hline
\end{tabular}

Table 5. Regression Results with Credit Rating on the Distance to Optimal Capital Structure Level

\begin{tabular}{|c|c|c|c|c|c|c|c|c|}
\hline \multicolumn{9}{|c|}{ Dependent Variable: Distance to Optimal Capital Structure Level } \\
\hline Coefficient & (1.1) & VIF score & (2.1) & VIF score & (3.1) & VIF score & (4.1) & VIF score \\
\hline Hausman & 0.00148 & & 0.002242 & & 0.00000 & & 0.00000 & \\
\hline White Test & 0.00000 & & 0.1798 & & 0.00000 & & 0.00000 & \\
\hline Wooldridge & 0.00000 & & 0.00016 & & 0.00000 & & 0.00000 & \\
\hline Constant & 2.14173 & & 1.67132 & & 2.14359 & & 2.58060 & \\
\hline $\mathrm{CR}$ & $-0.13668^{* * *}$ & 8.521276 & $0.06973^{* * *}$ & 12.207166 & $-0.13677^{* * *}$ & 8.799035 & -0.08389 & 10.718867 \\
\hline $\mathrm{I}\left(\mathrm{CR}^{2}\right)$ & $0.00861^{* * *}$ & 7.369871 & $-0.02315^{* * *}$ & 10.355810 & $0.01057^{* * *}$ & 6.363236 & 0.00684 & 7.472138 \\
\hline TANG & -0.00451 & 3.709577 & -0.18851 & 3.753164 & -0.30513 & 4.544570 & $0.74714^{*}$ & 4.133698 \\
\hline PROF & $0.36959^{* *}$ & 1.201957 & $-1.25310^{* * *}$ & 2.035349 & $-0.36929^{*}$ & 1.336819 & -0.49893 & 1.167972 \\
\hline LIQU & 0.00786 & 2.455895 & -0.00316 & 3.022430 & $0.01547^{* *}$ & 2.400219 & $0.05575^{* * *}$ & 2.401743 \\
\hline GROWTH & -0.02683 & 1.275291 & -0.01435 & 1.228520 & -0.06833 & 1.245745 & 0.03602 & 1.252379 \\
\hline SIZE & -0.03371 & 3.037397 & -0.04094 & 3.309809 & -0.04171 & 4.185630 & -0.09004 & 5.878825 \\
\hline Observations & 707 & & 155 & & 615 & & 1,212 & \\
\hline $\mathrm{R}^{2}$ & 0.56781 & & 0.87252 & & 0.76813 & & 0.57294 & \\
\hline Adjusted $\mathrm{R}^{2}$ & 0.54047 & & 0.86077 & & 0.75110 & & 0.54515 & \\
\hline F Statistic & $20.77050^{* * *}$ & & $74.23599^{* * *}$ & & $45.11659^{* * *}$ & & $20.61342^{* * *}$ & \\
\hline
\end{tabular}


The table exhibits the panel data regression result of 4 models with LTDTC to the IMLR as the proxy of optimal capital structure level, but with different credit rating agencies. Model 1.1 uses Standard \& Poor's, model 2.1 uses Moody's, model 3.1 uses Fitch, and model 4.1 uses PEFINDO's rating. The model applied a cross-sectional fixed effect. Time series is 41 quarters between 2011-2021. TANG is tangibility ratio; PROF is profitability ratio; LIQU is liquidity ratio; GROWTH is business growth; SIZE is firm size. The Hausman Test is to validate that the fixed effect model is more preferable than random effect; VIF score is to check multicollinearity; White test is to check heteroscedasticity; Wooldridge test is to check autocorrelation. Models with heteroscedasticity and/or autocorrelation problems use robust standard error estimation. *,**,*** indicates significance level at $10 \%, 5 \%$ and $1 \%$, respectively.

\subsection{Discussions}

Based on Table 4, there is a significant effect at $1 \%$ between Standard \& Poor's, Moody's, and Fitch credit rating on the capital structure level in the following year. Therefore, accept hypotheses using international rating agencies which are $\mathrm{H} 1, \mathrm{H} 2$, and $\mathrm{H} 3$. However, PEFINDO's rating shows insignificant impact thus rejecting $\mathrm{H} 4$.

The illustration graph of Standard \& Poor and Fitch ratings are shown in Figure 3. However, the exact skewness and turning point is not taken into account.
The result presents a non-linear U-shape relationship with the capital structure level in the following year. It means that firms with low and high credit rating levels tend to have a higher debt in the following year while the mid-rated firms have lower debt. High rated firms have a better reputation in fulfilling the financial obligations thus having an easier access to debt financing and do not require high interest offers. This opportunity seems to be employed by high-rated firms in Indonesia that have Standard \& Poor's or Fitch rating to issue more debt, thus supporting the trade-off theory. The findings aligned with Drobetz and Heller[10] and Krichene and Khoufi[8] but were also contradictory in terms of the low-rated firms. This research shows that low-rated firms have higher debt levels while the previous research stated that low-rated firms are likely to strengthen or even reduce their debt in order to repair the credit rating. The high debt level of low-rated firms could take place due to some probable scenario. First, firms may have no other methods to fund their financial activities due to poor operation, so they issue more debt. Second, firms that are projected to be unable to pay their debts could negotiate with debt holders to extend the debt maturity, resulting in higher payment in the future. However, this unusual occurrence is beyond the scope of this research and needs further research. On the other hand, the low debt level for mid-rated firms may be caused due to their preference of issuing equity instead of debt. Mid-rated firms might be more conservative in issuing debt to maintain their rating and prefer equity with better access than low-rated firms.

\section{Dependent Variable : Capstru (t+1)}

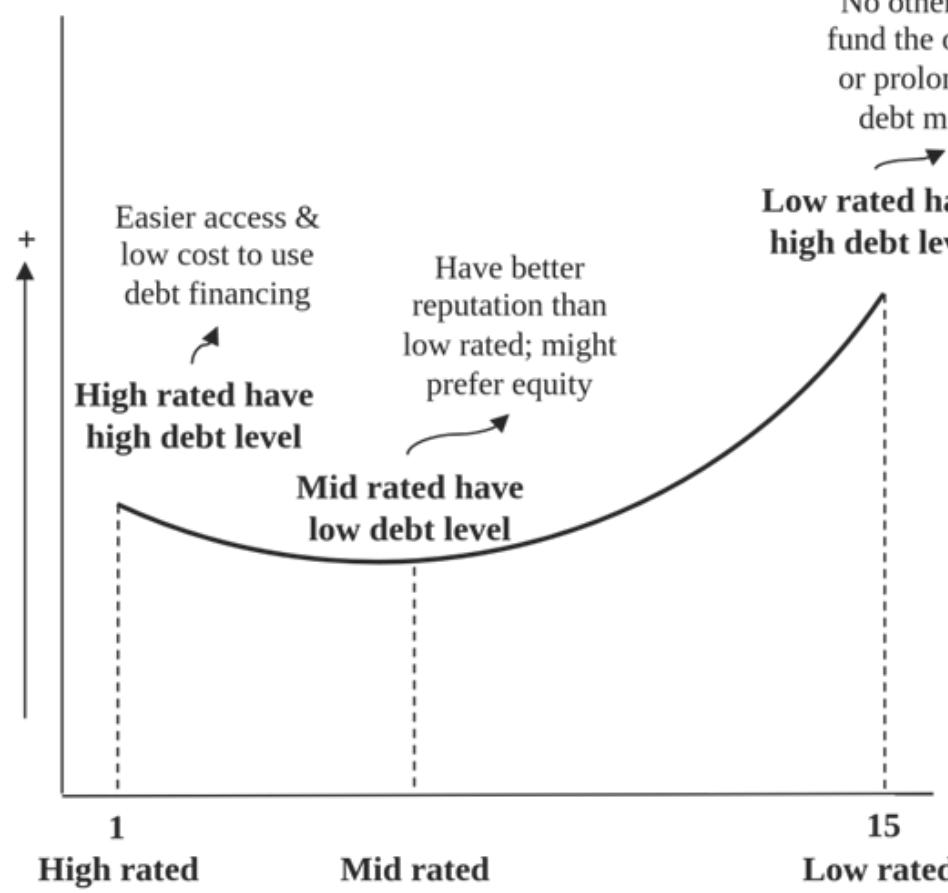

No other way to und the operation prolonged the bt maturity d have
Independent Variable: Credit Rating Level (t)

Figure 3. Illustration of Standard \& Poor's and Fitch Rating Relationship on Capital Structure Level 


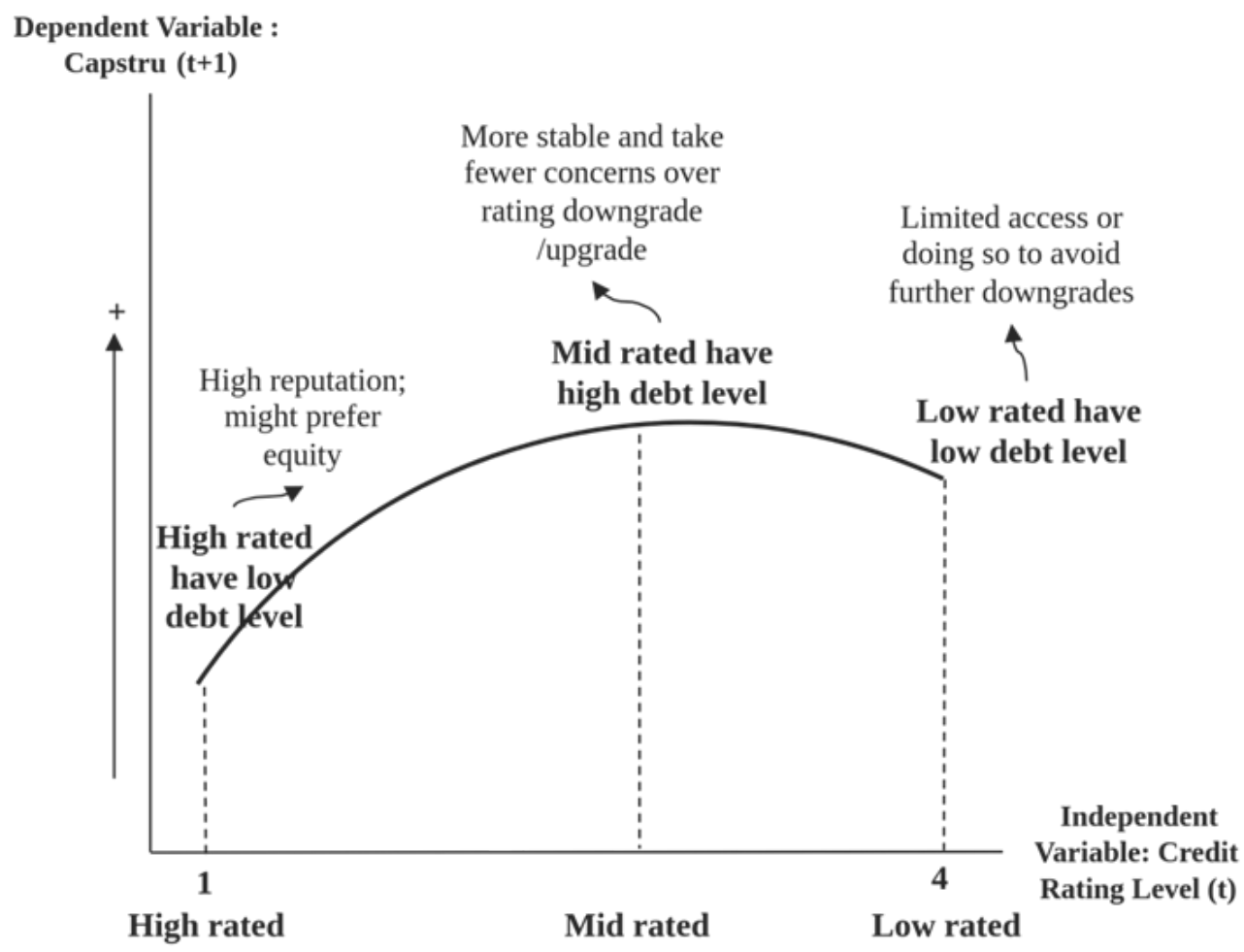

Figure 4. Illustration of Moody's Rating Relationship on Capital Structure Level

The illustration graph of Moody's rating is shown in Figure 4. However, the exact skewness and turning point is not taken into account.

Using Moody's rating, the result exhibits a non-linear inverted U-shape with the capital structure level in the following year. These findings support the previous research by Sajjad and Zakaria[12] and Ali and Javid[13]. It means that firms with low and high credit rating level tend to have a lower debt in the following year while the mid-rated firms have higher debt. High-rated firms are less opaque in the eyes of investors which lead up to lower information asymmetry, therefore decreasing the cost of equity financing and increasing the probability to issue equity. This opportunity seems to be employed by high-rated firms in Indonesia that have Moody's rating to issue more equity instead of debt. While for the low-rated firms, they also have lower debt that might be due to the limited access to debt financing and in order to avoid further downgrades. On the other hand, mid-rated firms have higher debt levels since they are more stable and take fewer concerns over rating downgrade or upgrade as compared to high and low rated firms.

Moving on to the second dependent variable which is the distance to optimal capital structure. Based on Table 5, there is a significant effect at $1 \%$ between Standard \& Poor's, Moody's, and Fitch credit rating on the distance to optimal capital structure level. Therefore, accept hypotheses using international rating agencies which are H5, H6, and H7. Moreover, PEFINDO's rating still shows insignificant impact thus rejecting $\mathrm{H} 8$.

The illustration graph of Standard \& Poor and Fitch ratings are shown in Figure 5. However, the exact skewness and turning point is not taken into account.

Using Standard \& Poor's and Fitch's credit rating, the result presents a non-linear U-shape relationship with the distance to optimal capital structure level in the following year. Following up the previous section, firms with low and high credit rating level tend to have a higher debt in the following year while the mid-rated firms have lower debt. Afterward, this section extends the impact of credit rating in terms of the distance to optimal capital structure level. Obtaining a similar result means that high-rated and low-rated firms have a higher debt and also a bigger distance to the optimal capital structure level. Thus, it can be concluded that they adjust their capital structure level and enjoy the advantages of debt financing without optimizing the distance to the optimal level, which fails to support the trade-off theory. On the other hand, mid-rated firms have lower debt levels and also a smaller distance to the optimal capital structure level. Thus, it can be concluded that they adjust their capital structure and enjoy equity financing to strengthen or improve their distance to optimal capital structure. 
Dependent Variable :

Distance to Optimal

Capital Structure $(t+1)$

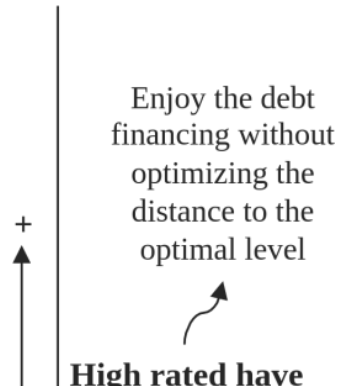

Enjoy the debt

financing without optimizing the distance to the optimal level

Low rated have bigger distance

Might be better in adjusting the capital structure level to its optimal level bigger distance

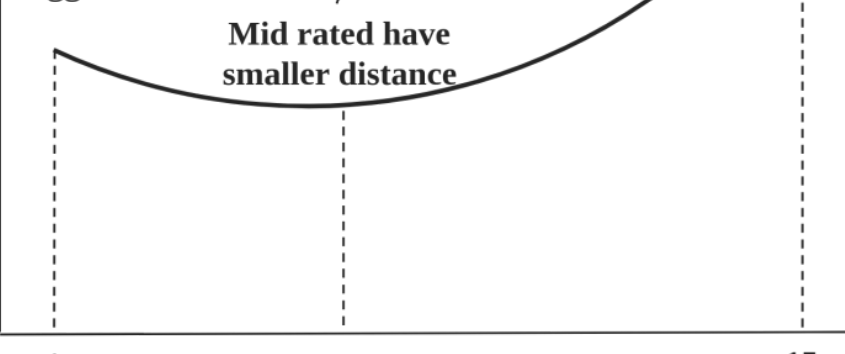

1

High rated

Independent

Variable: Credit

Rating Level (t)

Figure 5. Illustration of Standard \& Poor's and Fitch Rating Relationship on the Distance to Optimal Capital Structure Level

\section{Dependent Variable : \\ Distance to Optimal \\ Capital Structure (t+1)}

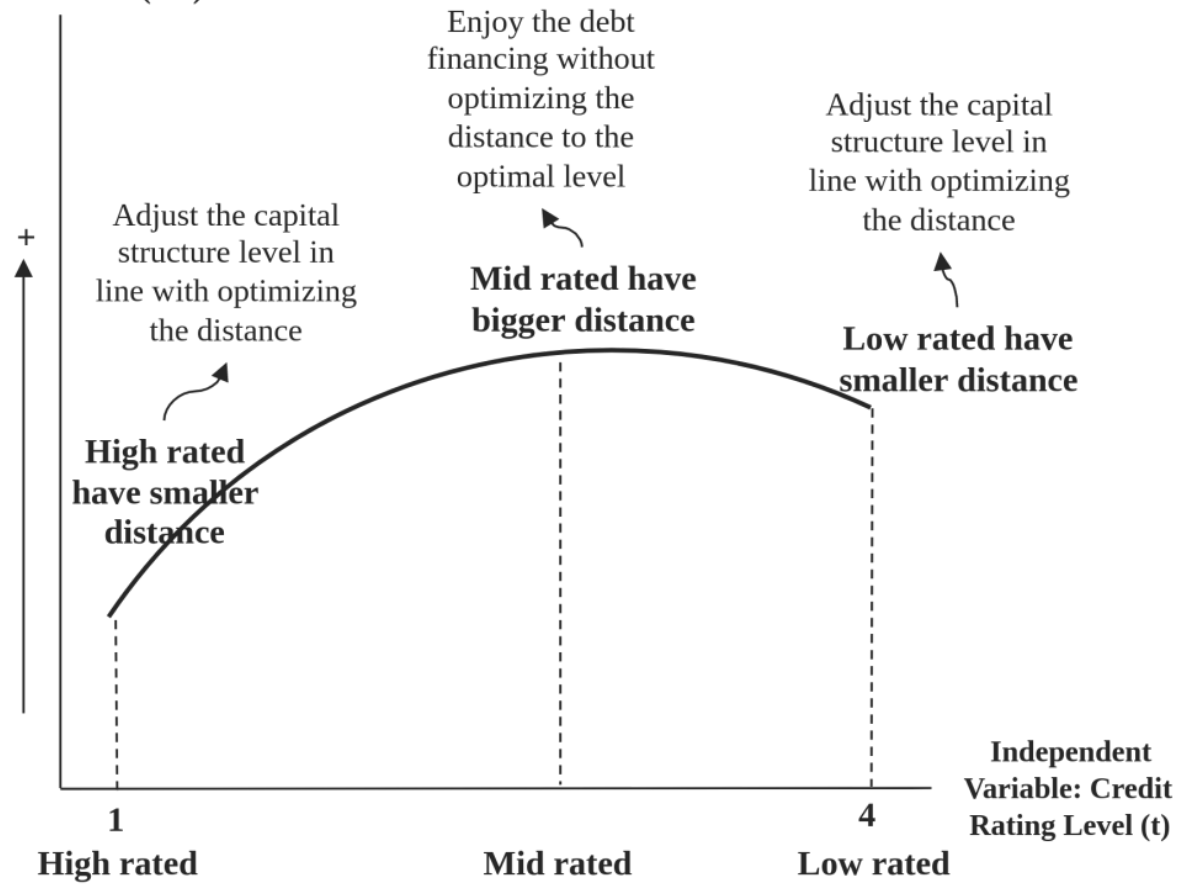

Figure 6. Illustration of Moody's Rating Relationship on the Distance to Optimal Capital Structure Level

The illustration graph of Moody's rating is shown in Figure 6. However, the exact skewness and turning point is not taken into account.

Using Moody's rating, the result exhibits a non-linear inverted U-shape with the distance to optimal capital structure level in the following year. Following up the previous section, firms with low and high credit rating level tend to have a lower debt in the following year while 
the mid-rated firms have higher debt. Following up the previous section, firms with low and high credit rating level tend to have a lower debt in the following year while the mid-rated firms have higher debt. Obtaining a similar non-linear U-shape result means that high-rated and low-rated firms have a lower debt and also a smaller distance to the optimal capital structure level. Thus, it can be concluded that they adjust their capital structure level in line with optimizing the distance to the optimal level. On the other hand, mid-rated firms have high debt levels and also a bigger distance to the optimal capital structure level. Thus, it can be concluded that they adjust their capital structure and enjoy debt financing without optimizing the distance to optimal capital structure.

The different results obtained between Standard \& Poor's, Fitch, and Moody's might be caused by different assessment criteria that are conducted by each international rating agency. Its differences might give different reactions to the firms. However, this research acknowledged that firm's sample using Moody's ratings is much less than using other rating agencies. Thus, expanding samples to other regions are recommended, especially to add samples of firms rated by Moody's.

Furthermore, this result also finds an interesting result which states that national rating from PEFINDO is insignificant on the capital structure decision of Indonesia listed firms. If we take a look back, the data using PEFINDO rating contains more stable conditions, meaning that the rating assigned doesn't change often. Moreover, there are high ratings issued which is idAAA using PEFINDO rating while using the international rating, the highest rating found is only BBB or the equal ratings. It might imply that PEFINDO as the national rating agency gave high ratings more easily and could cause firms to presume that the national ratings are no longer important in their capital structure decisions. The result using PEFINDO rating is in line with previous research that also examines PEFINDO ratings on capital structure[11].

The above results obtained are robust, meaning that excluding the firms with few sample observations and state-owned firms doesn't materially change the results. The relationship is still significant and the coefficient direction is still the same. This research also finds that tangibility, profitability, liquidity, and firm size have a significant impact on both dependent variables, while business growth has an insignificant impact.

\section{Conclusion and Recommendation}

With the panel data regression using fixed effect model, this research shows that firms with international credit rating of Standard \& Poor's and Fitch agency have a non-linear U-shape relationship to the capital structure level and to the distance to optimal capital structure in the following year. It means high-rated firms enjoy the advantages of high credibility and the debt financing even though the capital structure is getting more away than the optimal level. In contrast, firms with international credit rating of Moody's agency have a non-linear inverted U-shape relationship to the capital structure level and to the distance to optimal capital structure in the following year. On the other hand, the national credit rating of PEFINDO has no significant relationship at all with the capital structure level and to the distance to optimal capital structure in the following year.

This research finds that international credit rating is an important determinant of capital structure level in the following year. Non-rated firms in Indonesia could choose to obtain the international credit rating with the benefit given such as decreased information asymmetries due to creditworthiness scrutiny from the professional rating agency, resulting in better credibility validation and easier access to debt financing. However, obtaining credit rating does not always give a better access to debt financing if the rating is not maintained well. Firms should maintain their rating to ensure the stability of the access to issue debt. In depth, firms better incorporate the cost and benefit from rating with the cost and benefit from debt and equity financing, thus maintaining a certain desired rating and achieving the optimal level of capital structure.

For future research, adding a macroeconomic condition such as GDP growth, inflation, and real interest rate, as the control variables might give other findings about how the external conditions affect the firm's financing decision. Second, due to only a few Indonesia firms that are rated by the rating agencies, the sample used in this research is still limited and could not be distinguished based on every sector. Further research could also take into account the other regional firms such as Asian firms to enrich the sample and validate the findings. Third, this research applied the fixed effect panel regression technique which was quite restricted to include the lagged dependent variable as the independent variable. Therefore, future research could also apply Generalized Moment of Method regression technique which could efficiently take into account the lagged dependent variable as the independent variable since the current capital structure level may also be influenced by its previous value. Thus, including a lagged dependent variable as the regressor may also decrease the autocorrelation problem. Future research could compare the result with and without lagged dependent variable on the right side. Fourth, this research counts heavenly on the actual capital structure level with its optimal level. Future research might also want to examine the effect of credit rating with the net debt and net equity issuance, to capture the exact firm's choice of using rather retained earnings, debt, or equity, assessing the pecking order theory. Fifth, this research uses IMLR as the optimal level for the firms within a sector. To validate these research findings, future research could also 
try to calculate optimal capital structure for each individual since each firm might have their preference and condition. Sixth, future research might be needed to observe the difference between credit rating agencies. The different criteria and assessment process of each rating agency might affect the firm's behavior on dealing with their capital structure decisions. Lastly, for general purposes of capital structure research, credit rating, especially rating generated by the top three international agencies should be considered as one of the important determinants of capital structure level. Taking account of the credit rating as one of the determinants will ensure correct interpretations and provide a more accurate depiction of the behavior of firms regarding the capital structure decisions.

\section{Acknowledgements}

I thank God for the uncounted blessing and also my supervisor, family, and great friends who always support me throughout the making of this paper.

\section{REFERENCES}

[1] D. J. Kisgen, "Credit Ratings and Capital Structure," J. Finance, vol. 61, no. 3, pp. 1035-1072, 2006, doi: 10.1111/j.1540-6261.2006.00866.x.

[2] F. Bancel and U. R. Mittoo, "Cross-Country Determinants of Capital Structure Choice: A Survey of European Firms," Financ. Manag., vol. 33, no. 4, pp. 103-132, Dec. 2004.

[3] J. R. Graham and C. R. Harvey, "The theory and practice of corporate finance: Evidence from the field," J. financ. econ., vol. 60, no. 2-3, pp. 187-243, 2001, doi: $10.1016 / \mathrm{S} 0304-405 \mathrm{X}(01) 00044-7$.

[4] F. Modigliani and M. H. Miller, "The Cost of Capital, Corporation Finance and the Theory of Investment," Am. Econ. Rev., vol. 48, no. 3, pp. 261-297, 1958.

[5] F. Modigliani and M. H. Miller, "Corporate Income Taxes and the Cost of Capital: A Correction," Am. Econ. Rev., vol. 53, no. 3, pp. 433-443, 1963.

[6] E. F. Fama and K. R. French, "Testing Trade-Off and Pecking Order Predictions about Dividends and Debt," Rev. Financ. Stud., vol. 15, no. 1, pp. 1-33, Dec. 2002, doi: 10.1093/rfs/15.1.1.

[7] S. C. Myers and N. S. Majluf, "Corporate financing and investment decisions when firms have information that investors do not have," J. financ. econ., vol. 13, no. 2, pp. 187-221, 1984, doi: 10.1016/0304-405X(84)90023-0.

[8] A. F. Krichene and W. Khoufi, "The effects of credit rating grades ' changes on capital structure : S \& P 500," Int. J. Eng. Sci., vol. 5, no. 2, pp. 48-57, 2016.

[9] D. Rogers, W. Mendes-da-Silva, and P. Rogers, "Credit rating change and capital structure in Latin America," BAR -
Brazilian Adm. Rev., vol. 13, no. 2, pp. 1-22, 2016, doi: 10.1590/1807-7692bar2016150164.

[10] W. Drobetz and S. Heller, "The Impact of Credit Rating Changes on Capital Structure Decisions: Evidence from Non-Listed Firms in Germany," SSRN Electron. J., no. January, pp. 1-26, 2014, doi: 10.2139/ssrn.2392436.

[11] I. Febriansyah, "Signifikansi Credit Rating terhadap Struktur Modal (Studi Kasus: Perusahaan Indonesia)," Perpust. Digilib ITB, 2010, https://digilib.itb.ac.id/index.p $\mathrm{hp} / \mathrm{gdl} / \mathrm{view} / 16068$.

[12] F. Sajjad and M. Zakaria, "Credit Rating as a Mechanism for Capital Structure Optimization: Empirical Evidence from Panel Data Analysis," Int. J. Financ. Stud., vol. 6, no. 1, p. 13, 2018, doi: 10.3390/ijfs6010013.

[13] S. Ali and A. yasmin Javid, "Relationship between Credit Rating, Capital Structure and Earning Management Behaviour," Pakistan Inst. Dev. Econ., vol. 121, pp. 1-50, 2015.

[14] M. Wojewodzki, W. P. H. Poon, and J. Shen, "The role of credit ratings on capital structure and its speed of adjustment: an international study," Eur. J. Financ., vol. 24, no. $9, \quad$ pp. 735-760, 2018, doi: 10.1080/1351847X.2017.1354900.

[15] V. Anand and K. A. Soomro, "Determinants of Credit Rating and Optimal Capital Structure among Pakistani Banks," Rom. Econ. J., vol. 19, no. 60, pp. 169-182, 2016.

[16] S. S. Mirza, K. Jebran, Y. Yan, and A. Iqbal, "Financing behavior of firms in tranquil and crisis period: Evidence from China," Cogent Econ. Financ., vol. 5, no. 1, pp. 1-17, 2017, doi: 10.1080/23322039.2017.1339770.

[17] K. L. H. Khaw, "Debt financing puzzle and internationalization," J. Asia Bus. Stud., vol. 13, no. 1, pp. 33-56, 2019, doi: 10.1108/JABS-01-2017-0001.

[18] A. Chakrabarti and A. Chakrabarti, "The capital structure puzzle - evidence from Indian energy sector," Int. J. Energy Sect. Manag., vol. 13, no. 1, pp. 2-23, 2019, doi: 10.1108/IJESM-03-2018-0001

[19] G. Workman and D. Rosenberg, "a Financial Analysis of Those Firms in Emerging Markets With the Greatest Capital Expenditures in a Period of Decline," Southwest. Econ. Rev., vol. 46, pp. 17-29, 2019.

[20] S. S. Shah, S. A. Pitafi, and A. Soomro, "The Nexus Between Capital Structure And Firms' Profitability: Evidence From Oil \& Gas Sector of Pakistan," J. Bus. Strateg., vol. 13, no. 1, pp. 109-124, 2019, doi: 10.29270/jbs.13.1(2019).077.

[21] S. Titman and R. Wessels, "The Determinants of Capital Structure Choice," J. Finance, vol. 43, no. 1, pp. 1-19, Mar. 1988, doi: 10.1111/j.1540-6261.1988.tb02585.x.

[22] T. P. N. Nguyen, P. L. Nguyen, and T. T. H. Dang, "Analyze the determinants of capital structure for Vietnamese real estate listed companies," Int. J. Econ. Financ. Issues, vol. 7, no. 4, pp. 270-282, 2017.

[23] S. C. Myers, “The Capital Structure Puzzle," J. Finance, vol. 39 , no. 3, p. 575, 1984, doi: 10.2307/2327916.

[24] M. Mouton and N. Smith, "Company determinants of 
capital structure on the JSE Ltd and the influence of the 2008 financial crisis," J. Econ. Financ. Sci., vol. 9, no. 3, pp. 789-806, 2016, doi: 10.4102/jef.v9i3.71.

[25] M. Nadeem, R. Ahmad, A. Ahmed, N. Ahmad, and S. Rabia Batool, "The Effect of Leverage on Financial Health of the Firms: A Study from Cement Industry of Pakistan," Ind. Eng. Lett., vol. 5, no. 5, pp. 123-127, 2015, https://www.iiste.org/Journals/index.php/IEL/article/view/ $22277 / 22783$

[26] R. M. Hull, "Leverage Ratios, Industry Norms, and Stock Price Reaction: An Empirical Investigation of Stock-for-Debt Transactions," 1999.

[27] P. Naomi, I. A. Ekaputra, and B. Wibowo, "The role of industrial factors on optimal capital structure proxy: An empirical study on Indonesia manufacture companies," Serbian J. Manag., vol. 13, no. 1, pp. 105-113, 2018, doi: 10.5937/sjm13-16216.

[28] A. Hovakimian, G. Hovakimian, and H. Tehranian, "Determinants of target capital structure: the case of combined debt and equity financing," J. Financ. Quant. Anal., vol. 36, pp. 1-24, Jan. 2004.

[29] M. Z. Frank and V. K. Goyal, "Capital Structure Decisions: Which Factors Are Reliably Important?," Financ. Manag., vol. 38, no. 1, pp. 1-37, Jun. 2009, [Online]. Available: http://www.jstor.org/stable/20486683.

[30] L. Booth, V. Aivazian, A. Demirguc-Kunt, and V. Maksimovic, "Capital Structure in Developing Countries," J. Finance, vol. 56, pp. 87-130, Feb. 2001, doi: 10.1111/0022-1082.00320.

[31] M. Harris and A. Raviv, "The Theory of Capital Structure," The Journal of Finance, vol. 46, no. 1. John Wiley \& Sons, Ltd, pp. 297-355, Mar. 01, 1991, doi: 10.1111/j.1540-6261.1991.tb03753.x.

[32] J. B. Warner, "Bankruptcy Costs: Some Evidence," J. Finance, vol. 32, no. 2, pp. 337-347, Jun. 1977, doi: $10.2307 / 2326766$.

[33] Mi. G. Ferri and W. H. Jones, "Determinants of Financial Structure: a New Methodological Approach," J. Finance, vol. 34, no. 3, pp. 631-644, Jun. 1979, doi: 10.1111/j.1540-6261.1979.tb02130.x.

[34] J. Chen and R. Strange, "The Determinants of Capital Structure: Evidence from Chinese Listed Companies," Econ. Chang. Restruct., vol. 38, pp. 11-35, Mar. 2005, doi: 10.1007/s10644-005-4521-7.

[35] S. D. Prowse, "Institutional investment patterns and corporate financial behavior in the United States and Japan," J. financ. econ., vol. 27, no. 1, pp. 43-66, 1990, doi: $10.1016 / 0304-405 X(90) 90020-Z$.

[36] A. Shleifer and R. W. Vishny, "Liquidation Values and Debt Capacity: A Market Equilibrium Approach," $J$. Finance, vol. 47, no. 4, pp. 1343-1366, Jun. 1992, doi: $10.2307 / 2328943$.

[37] S. C. Myers, "Determinants of corporate borrowing," $J$. financ. econ., vol. 5, no. 2, pp. 147-175, 1977, doi: 10.1016/0304-405X(77)90015-0.

[38] A. Bevan and J. Danbolt, "Capital Structure and its Determinants in the UK - A Decompositional Analysis," Appl. Financ. Econ., vol. 12, pp. 159-170, Feb. 2002, doi: $10.2139 /$ ssrn.233550.

[39] D. N. Gujarati and D. C. Porter, "Panel Data Regression Model", in Basic Econometrics, 5th ed. McGraw-Hill Irwin, 2009, pp. 591-612. 